\title{
Secondary dementia due to Lyme neuroborreliosis
}

\author{
Wolfgang Kristoferitsch · Fahmy Aboulenein-Djamshidian · Julia Jecel · Helmut Rauschka • Michael Rainer • \\ Gerold Stanek - Peter Fischer
}

Received: 22 March 2018 / Accepted: 28 June 2018 / Published online: 25 July 2018

(c) The Author(s) 2018

Summary Dementia-like syndromes are rare manifestations of Lyme neuroborreliosis. The clinical patterns are summarized using our own cases and case reports from the literature, which were diagnosed as definite Lyme neuroborreliosis according to the European guidelines. The cases disclose signs of subcortical dementia that occur more rapidly than in patients suffering from primary dementia. Gait disturbances early in the disease course is another frequently observed characteristic feature. The response to 2-4 weeks of antibiotic treatment with ceftriaxone was excellent. There were no indications for a prolonged antibiotic treatment. It is essential to be aware of this manifestation of Lyme neuroborreliosis, because early antibiotic treatment will prevent permanent sequelae that may occur throughout the further course of the untreated disease.

W. Kristoferitsch · F. Aboulenein-Djamshidian · H. Rauschka Karl Landsteiner Institute for Neuroimmunological and Neurodegenerative Disorders, SMZ-Ost-Donauspital, Vienna, Austria

F. Aboulenein-Djamshidian

fahmy.aboulenein-djamshidian@wienkav.at

H. Rauschka

helmut.rauschka@wienkav.at

F. Aboulenein-Djamshidian $\cdot$ H. Rauschka

Neurological Department, SMZ-Ost-Donauspital, Vienna, Austria

J. Jecel

Neurological Department 2, NRK Rosenhügel, Vienna,

Austria

julia.jecel@wienkav.at

M. Rainer · P. Fischer

Psychiatric Department, SMZ-Ost-Donauspital, Vienna, Austria
Keywords Lyme borreliosis · Lyme disease - Cognitive impairment - Antibiotic treatment · Normal pressure hydrocephalus
Abbreviations
AD Alzheimer's disease
AI Borrelia burgdorferi specific antibody in-
$\mathrm{Bb} \quad$ Box $\quad$ Borrelia burgdorferi
BS Banwarth's syndrome
cCT Cranial computed tomography
CERAD Consortium to Establish a Registry for
Alzheimer's Disease
CNS Central nervous system
CSF Cerebrospinal fluid
DAT Dopamin transporter
DLB Dementia with Lewy bodies 
DMS Diagnostic and Statistical Manual of Mental Disorders

EFNS European Federation of Neurological Societies

EM Erythema migrans

FDG-PET Fluorodeoxyglucose positron emission tomography

IATI Innotest-amyloid-tau index

IDSR Intercategorical Delayed Selective Reminding test

LB Lyme borreliosis

LD Lyme disease

LNB Lyme neuroborreliosis

MMSE Mini Mental State Examination

MRI Magnetic resonance imaging

NPH Normal pressure hydrocephalus

STT Spinal tap test

WML White matter lesions

WMS-R Wechsler Memory Scale-Revised

\section{Introduction}

Dementia as a dominant symptom of meningoencephalitis in Lyme neuroborreliosis (LNB) is extremely rare. Only few reports on definite cases with LNB exist, when guidelines of the European Federation of Neurological Societies (EFNS) on diagnosis of LNB are applied [1]; however, it has been argued that dementialike syndromes associated with Lyme borreliosis (LB) or Lyme disease (LD) occur more frequently when less stringent diagnostic criteria are used and that infections with Borrelia burgdorferi (Bb) may even cause or trigger primary dementia, such as Alzheimer's disease (AD) [2-4]. The aim of this study was to characterize the clinical picture of dementia-like syndromes in definitive LNB, thus raising the awareness of this rare disorder. This should result in an early diagnosis and successful antibiotic treatment, as long as clinical symptoms are still completely reversible.

\section{Material and methods}

Between 2004 and 2017, a total of 3 patients with a dementia-like syndrome and definite LNB were diagnosed at the neurological and at the psychiatric department of SMZ-Ost-Donauspital, a tertiary health facility. All patients fulfilled the EFNS guidelines for definitive LNB. Before LNB was diagnosed the clinical picture was consistent with the Diagnostic and Statistical Manual of Mental Disorders (DMS) IV criteria for dementia [5] and with the DMS-5 criteria for severe cognitive impairment, which have replaced the term dementia [6]. This article reports data from one of the three patients in detail. Data from the other two patients have been previously reported [7, 8]. For these two cases follow-up data will be reported.

To evaluate the frequency of this rare manifestation of LNB, patient files from 1 January 2004 to 31 December 2017 were searched at the neurological depart- ment of SMZ-Ost-Donauspital for all cases with LNB. In addition, a PubMed search was performed using the following keywords: "Neuroborreliosis" AND "Dementia", "Neuroborreliosis" AND "Cognitive impairment", "Neuoborreliosis" AND "Alzheimer's disease", "Neuroborreliosis" AND "Alzheimer", "Neuroborreliosis" AND "Normal pressure hydrocephalus". "Lyme disease", and "Lyme Borreliosis" were also used as keywords instead of "Neuroborreliosis". A total of 119 hits were retrieved. From these and other publications those 10 patients with detailed clinical information were selected. Of these 10 patients 2 with additional HIV positivity [9] and 1 patient with progressive supranuclear paralysis were excluded [10]. Cases which did not fulfil EFNS guidelines for definitive LNB $[2,11,12]$, cases with definitive LNB and dementia, that did not present enough data for the individual patient $[13,59]$ and cases with cognitive impairment of less than 2 months duration [14, 15] were not included. Using diagnostic guidelines valid for European LNB our review was restricted to European cases with LNB.

\section{Case reports}

Patient 10 (Tables 1 and 2), a 76-year-old female, was referred to the department of neurology in July 2012 because of progressing cognitive decline over the last 12 months, loss of weight, nausea, gait disturbance and tremor. She was seen on May 2011 for the first time by a neurologist with a 3-month history of dull holocephalic headache who ordered a cranial magnetic resonance imaging (MRI) and diagnosed a tension-type headache and a depressive disorder. Treatment with an antidepressant (duloxetine) was started. The patient experienced no improvement and a second examination by another neurologist was undertaken 2 months later. Again no focal neurological signs could be detected. Due to the weight loss, an occult neoplasm was suspected but not detected during an extensive inpatient investigation at a medical department during February 2012; however, the MRI showed bilateral white matter lesions (WML) and an old lacunar lesion located at the left striatum, the latter was not seen in the previous MRI from May 2011. Since the patient also suffered from mild hypertension, vascular encephalopathy was thought to be the cause of the progressive cognitive decline. Extensive neurocognitive testing was carried out in a rehabilitation centre in May 2012 and disclosed a severe decline of attention, memory and executive functions corresponding to subcortical dementia (Fig. 1). When the patient was seen for a further diagnostic work-up at the SMZ-Ost-Donauspital in July 2012, the weight was $47 \mathrm{~kg}$ and a weight loss of $20 \mathrm{~kg}$ was reported over the past year. The gait was insecure with postural instability and with a tendency to fall when turning around. Frontal signs were positive, the voice was quiet, the tonus was mildly elevated and showed a slight hes- 


\section{Lyme Borreliosis}

Table 1 Clinical- and treatment-data of 10 patients with dementia like syndromes due to Lyme neuroborreliosis. Literature search and own cases

\begin{tabular}{|c|c|c|c|c|c|c|c|c|c|c|c|}
\hline $\begin{array}{l}\text { (Patient } \\
\text { number), } \\
\text { age at di- } \\
\text { agnosis } \\
\text { (years), } \\
\text { sex, (refer- } \\
\text { ence) }\end{array}$ & $\begin{array}{l}\text { History } \\
\text { of tick } \\
\text { bite, EM } \\
\text { or BS }\end{array}$ & $\begin{array}{l}\text { Duration of } \\
\text { symptoms } \\
\text { prior to TX }\end{array}$ & Weight-lo & $\begin{array}{l}\text { Nausea, } \\
\text { malaise, } \\
\text { vomit- } \\
\text { ing }\end{array}$ & Head-ach & $\begin{array}{l}\text { Voiding } \\
\text { dysfunc- } \\
\text { tion }\end{array}$ & Tremor & $\begin{array}{l}\text { Falls, gait } \\
\text { distur- } \\
\text { bance }\end{array}$ & $\begin{array}{l}\text { Other } \\
\text { focal neu- } \\
\text { rological } \\
\text { signs }\end{array}$ & Neuroimaging & $\begin{array}{l}\text { STT re- } \\
\text { sponse }\end{array}$ \\
\hline $\begin{array}{l}\text { (1) } 60 \text {, } \\
\text { male [53] }\end{array}$ & $\begin{array}{l}\text { EM? } \\
12 \mathrm{~m}^{\mathrm{a}} \\
\mathrm{BS} ? \\
11 \mathrm{~m}^{\mathrm{a}}\end{array}$ & $6 m$ & $\mathrm{Nm}$ & $\mathrm{Nm}$ & $\mathrm{Nm}$ & + & $\mathrm{Nm}$ & + & No & cCT: normal & $\mathrm{Nm}$ \\
\hline $\begin{array}{l}\text { (2) } 74, \\
\text { female [54] }\end{array}$ & No & $8 m$ & $\mathrm{Nm}$ & $\mathrm{Nm}$ & $\mathrm{Nm}$ & + & $\mathrm{Nm}$ & + & No & $\begin{array}{l}\text { MRI: ventricular dilatation, } \\
\text { patch-like subependymal } \\
\text { signal abnormalities, } \\
\text { compatible with NPH }\end{array}$ & Yes/no \\
\hline $\begin{array}{l}\text { (3) } 33 \text {, } \\
\text { male [55] }\end{array}$ & No & $8 m$ & $\mathrm{Nm}$ & $\mathrm{Nm}$ & $\mathrm{Nm}$ & $\mathrm{Nm}$ & $\mathrm{Nm}$ & + & $\begin{array}{l}\text { Pyramidal } \\
\text { signs }\end{array}$ & $\begin{array}{l}\text { MRI: small hyperintense } \\
\text { lesions close to cornu } \\
\text { anterior and capsula } \\
\text { externa }\end{array}$ & $\mathrm{Nm}$ \\
\hline $\begin{array}{l}\text { (4) } 76 \\
\text { male } \\
{[56]}\end{array}$ & $\mathrm{Nm}$ & $6 m$ & + & $\mathrm{Nm}$ & $\mathrm{Nm}$ & + & $\mathrm{Nm}$ & + & No & $\begin{array}{l}\text { MRI: ventricular dilatation } \\
\text { suggesting NPH }\end{array}$ & $\mathrm{Nm}$ \\
\hline $\begin{array}{l}\text { (5) } 83, \\
\text { female [57] }\end{array}$ & $\begin{array}{l}\text { Repeated } \\
\text { tick bites }\end{array}$ & $6 m$ & $5-7 \mathrm{~kg}$ & $\mathrm{Nm}$ & $\mathrm{Nm}$ & + & + & + & Diplopia & $\begin{array}{l}\text { MRI: leukoaraiosis, is- } \\
\text { chemic lesion near left } \\
\mathrm{N} \text { lentiformis, enlarged } \\
\text { ventricles suspicious for } \\
\mathrm{NPH}\end{array}$ & Yes/yes \\
\hline $\begin{array}{l}\text { (6) } 69 \text {, } \\
\text { female [39] }\end{array}$ & $\begin{array}{l}\text { Remote } \\
\text { tick bites }\end{array}$ & $12 m$ & $\mathrm{Nm}$ & $\mathrm{Nm}$ & $\mathrm{Nm}$ & + & $\mathrm{Nm}$ & + & $\begin{array}{l}\text { Babinski, } \\
\text { leg weak- } \\
\text { ness }\end{array}$ & $\begin{array}{l}\text { MRI: symmetrical WML, } \\
\text { meningeal GAD enhance- } \\
\text { ment }\end{array}$ & $\mathrm{Nm}$ \\
\hline $\begin{array}{l}\text { (7) } 75 \text {, } \\
\text { female [58] }\end{array}$ & No & $10 \mathrm{~m}$ & $\mathrm{Nm}$ & + & + & + & $\mathrm{Nm}$ & + & $\begin{array}{l}\text { Rigor, } \\
\text { brady-ki- } \\
\text { nesia }\end{array}$ & $\begin{array}{l}\text { MRI: mild periventricular } \\
\text { white matter changes, } \\
\text { widening of the lateral } \\
\text { ventricles, Evans index } \\
0.34\end{array}$ & $\begin{array}{l}\mathrm{CSF} \\
<10 \mathrm{ml}\end{array}$ \\
\hline $\begin{array}{l}\text { (8) } 80, \\
\text { female [7] }\end{array}$ & No & $6 m$ & $\mathrm{Nm}$ & $\mathrm{Nm}$ & $\mathrm{Nm}$ & + & + & $(+)$ & No & $\begin{array}{l}\text { MRI: enlarged ventricles, } \\
\text { periventricular lesions }\end{array}$ & Yes/yes \\
\hline $\begin{array}{l}\text { (9) } 71 \text {, } \\
\text { female [8] }\end{array}$ & $\begin{array}{l}\text { Tick bite } \\
\text { EM? } \\
4 \mathrm{~m}^{\mathrm{a}}\end{array}$ & $3 m$ & $15 \mathrm{~kg}$ & + & + & + & + & + & No & $\begin{array}{l}\text { MRI: ventricles enlarged, } \\
\text { bilateral mesiotemporal } \\
\text { atrophy, widened insular } \\
\text { cistern, cella media index } \\
3.4 \text {. } \\
\text { FDG-PET: normal }\end{array}$ & No \\
\hline $\begin{array}{l}\text { (10) } 77 \text {, } \\
\text { female }\end{array}$ & No & $12 m$ & $20 \mathrm{~kg}$ & + & + & $\mathrm{Nm}$ & + & + & No & $\begin{array}{l}\text { MRI: bilateral WML, stri- } \\
\text { atal lacunar lesion. } \\
\text { FDG-PET: frontotemporal } \\
\text { hypo-metabolism }\end{array}$ & No \\
\hline
\end{tabular}

itancy ("Gegenhalten"), tendon reflexes were brisk, paresis and pyramidal signs missing. There were no signs of ataxia, but a mild bradykinesia. Action tremor was more distinct than a mild resting tremor. Again, neurocognitive testing and gait disturbances were consistent with subcortical dementia (Figs. 2 and 3). Regarding the mild signs of parkinsonism, dementia with Lewy bodies (DLB) was also suspected but excluded by a dopamine transporter (DAT) scan. Fluorodeoxyglucose positron emission tomography (FDG-PET) demonstrated hypometabolism in the left striatum and in the left frontotemporal cortex (Fig. 4).
Cerebrospinal fluid (CSF) showed signs of a chronic lymphocytic inflammation. The CSF markers for dementia, total tau protein and phosphor-tau were within the normal range, while beta-amyloid 1-42 and the Innotest-amyloid-tau index (IATI) were found to be below the reference values (beta-amyloid 1-42: $290 \mathrm{pg} / \mathrm{ml}$, reference value $>500 \mathrm{pg} / \mathrm{ml}$; IATI 0.6 , reference values $>1$ ). Finally, LNB was diagnosed when further CSF examinations disclosed a highly elevated $\mathrm{Bb}$-specific-AI indicating local intrathecal Bb-specific antibody synthesis (Table 2). The patient was treated with $2 \mathrm{~g}$ ceftriaxone daily for 3 weeks. 
Table 2 Clinical- and treatment-data of 10 patients with dementia like syndromes due to Lyme neuroborreliosis. Literature search and own cases

\begin{tabular}{|c|c|c|c|c|}
\hline $\begin{array}{l}\text { (Patient number), reference } \\
\text { TX, follow-up }\end{array}$ & $\begin{array}{l}\text { Pre-/post-TX: cognitive impair- } \\
\text { ment, MRI }\end{array}$ & MMSE & Pre-/post-TX: other neurocognitive tests & Pre-/post-TX: CSF \\
\hline (1), [53] & $\begin{array}{l}\text { Loss of memory and orientation } \\
\text { in time, unable to cope with daily } \\
\text { activities }\end{array}$ & $\mathrm{Nm}$ & $\mathrm{Nm}$ & Cc: $285 / \mu l ;$ tp: 3600 mg/l \\
\hline 2 w benzylpenicillin IV & $\begin{array}{l}\text { Mental condition improved, mem- } \\
\text { ory poor, needs daily help ( } 1 \text { year } \\
\text { after TX) }\end{array}$ & $\mathrm{Nm}$ & $\mathrm{Nm}$ & $\begin{array}{l}\text { Cc: } 88 / \mu l ; \text { tp: } 700 \mathrm{mg} / \mathrm{l} \mathrm{Al:} \\
20\end{array}$ \\
\hline (2), [54] & $\begin{array}{l}\text { Reduced attention and memory, } \\
\text { confused, completely dependent }\end{array}$ & $20 / 30$ & $\begin{array}{l}\text { Digit-symbol (WAIS): } 3 \text {; CAT: phasic and } \\
\text { tonic alertness at least } 1 \text { sd below controls }\end{array}$ & $\begin{array}{l}\text { Cc: } 89 / \mu l ; \text { tp: } 1910 \mathrm{mg} / \mathrm{l} \\
\text { OCB+; Al: } 12.6\end{array}$ \\
\hline $18 \mathrm{~m}$ after $2 \mathrm{w} c$ & $\begin{array}{l}\text { Memory normal, independent; MRI: } \\
\text { idem }\end{array}$ & $29 / 30$ & Digit symbol: 11 ; CAT: $>1$ sd above controls & $\begin{array}{l}\text { Cc: } 2 / \mu l ; \text { tp: } 290 \mathrm{mg} / \mathrm{l} ; \mathrm{Al}: \\
>12.5\end{array}$ \\
\hline (3), [55] & $\begin{array}{l}\text { Progressing impairment of memory } \\
\text { and concentration }\end{array}$ & $\mathrm{Nm}$ & $\mathrm{Nm}$ & $\begin{array}{l}\text { Cc: } 51 / \mu l ; \text { tp: } 260 \mathrm{mg} / \mathrm{l} ; \\
\text { OCB+; Al+ }\end{array}$ \\
\hline $9 \mathrm{~m}$ after start of $2 \mathrm{w} c$ & $\begin{array}{l}\text { Major regression of cognitive } \\
\text { impairment }\end{array}$ & $\mathrm{Nm}$ & $\mathrm{Nm}$ & Cc: $6 / \mu \mathrm{l} ; \mathrm{Al}+$ \\
\hline (4), [56] & $\begin{array}{l}\text { Amnesia for recent events, disori- } \\
\text { entation }\end{array}$ & $15 / 30$ & Mattis Scale 98/144 & $\begin{array}{l}\text { Cc: } 250 / \mu l ; \text { tp: } 3000 \mathrm{mg} / \mathrm{dl} \\
\text { (sic); Al: } 19.7\end{array}$ \\
\hline $\begin{array}{l}4 \text { w after start of } 4 \text { ? or } \\
12 ? \text { w c }\end{array}$ & $\begin{array}{l}\text { No cognitive impairment after } \\
\text { reassessment; MRl: unchanged } \\
\text { after } 1 \mathrm{~m}\end{array}$ & \multicolumn{2}{|c|}{ "No impairment in neurocognitive tests" } & $\begin{array}{l}\text { "CSF normal" (12w after } \\
\text { start of TX) }\end{array}$ \\
\hline (5), [57] & $\begin{array}{l}\text { Impairment of memory and } \\
\text { "wordfinding" }\end{array}$ & $18 / 30$ & $\begin{array}{l}\text { CERAD: impairment of vf and recall of world } \\
\text { list }\end{array}$ & $\begin{array}{l}\text { Cc: } 69 / \mu \mathrm{ll} ; \mathrm{tp:} 3542 \mathrm{mg} / \mathrm{l} ; \\
\text { lactate: } 4.8 \mathrm{mmol} / \mathrm{l} ; \mathrm{Al}: 31.1\end{array}$ \\
\hline $\begin{array}{l}7 \mathrm{~m} \text { after } 2 \mathrm{w} \text { c followed by } \\
3 \mathrm{~m} \mathrm{a}\end{array}$ & $\begin{array}{l}\text { No memory problems, no problems } \\
\text { with daily activities }\end{array}$ & $27 / 30$ & CERAD: vf, recall of world list improved & $\mathrm{Nd}$ \\
\hline (6), [39] & $\begin{array}{l}\text { Rapidly progressing dementia, } \\
\text { short-term memory severely im- } \\
\text { paired, disoriented }\end{array}$ & $\mathrm{Nm}$ & $\mathrm{Nm}$ & $\begin{array}{l}\text { Cc: } 44 / \mu l ; \text { alb: } 3570 \mathrm{mg} / \mathrm{l} ; \\
\text { lactate: } 6.1 \mathrm{mmol} / / ; \text { OCB-; } \\
\text { Al: } 10.5\end{array}$ \\
\hline $5 \mathrm{~m}$ after $3 \mathrm{w} c$ & $\begin{array}{l}\text { No signs of cognitive impairment; } \\
\text { MRI: improvement after } 5 y\end{array}$ & $\mathrm{Nm}$ & $\mathrm{Nm}$ & Alb: 244 mg/l; Al: 581 \\
\hline (7), [58] & $\begin{array}{l}\text { Not fully oriented, attention, con- } \\
\text { centration and short-term memory } \\
\text { reduced }\end{array}$ & $20 / 30$ & $\mathrm{Nm}$ & $\begin{array}{l}\text { Cc: } 30 / \mu l ; \text { tp: } 1540 \mathrm{mg} / \mathrm{l} ; \\
\text { lactate: } 2.9 \mathrm{mmol} / \mathrm{l} ; 0 \mathrm{CB}+; \\
\text { Al: } 18.5\end{array}$ \\
\hline $\begin{array}{l}\text { a) } 3 w \text {, b) } 4 \mathrm{~m} \text { and c) } 15 \mathrm{~m} \text { after } \\
3 \mathrm{w} c\end{array}$ & $\begin{array}{l}\text { a), b) and c): complete remission; } \\
\text { MRI: unchanged after } 15 \mathrm{~m}\end{array}$ & $\begin{array}{l}\text { a) } 28 / 30 \\
\text { b) } 30 / 30 \\
\text { c) } 30 / 30\end{array}$ & $\mathrm{Nm}$ & $\begin{array}{l}\text { Cc: a) } 19 \text { b) } 3 / \mu l \text {; tp: a) } 540 \\
\text { b) } 390 \mathrm{mg} / \mathrm{l} \\
\text { lactate: a) } 1.9 \text { b) } 1.6 \mathrm{mmol} / \mathrm{l} \\
\text { OCB (a and b)+; Al: a) } 21.1 \text { : } \\
\text { b) } 49.9\end{array}$ \\
\hline (8), [7] & $\begin{array}{l}\text { Reduced attention and memory, } \\
\text { amnesia for recent events, spa- } \\
\text { tiotemporal disorientation }\end{array}$ & $21 / 30$ & $\mathrm{Nm}$ & $\begin{array}{l}\text { Cc: } 45 / \mu l ; \text { tp: } 523 \mathrm{mg} / \mathrm{l} ; \\
\text { OCB+; Al: } 13.6\end{array}$ \\
\hline $2 \mathrm{~m}$ after start of $4 \mathrm{w} c$ & $\begin{array}{l}\text { Complete recovery; MRI: un- } \\
\text { changed }\end{array}$ & $29 / 30$ & $\mathrm{Nm}$ & $\begin{array}{l}\text { Cc: } 7 / \mu l ; \text { tp: } 370 \mathrm{mg} / \mathrm{l} ; \\
\text { OCB+; Al: } 10.9\end{array}$ \\
\hline (9), [8] & $\begin{array}{l}\text { Spatiotemporal disoriented, re- } \\
\text { duced attention and memory, optic } \\
\text { hallucinations }\end{array}$ & $17 / 30$ & $\begin{array}{l}\text { IDSR-5: -3.51, IDSR-7: -2.149 (z-score); } \\
\text { CDT: } 3 / 9\end{array}$ & $\begin{array}{l}\text { Cc: } 321 / \mu l ; \text { tp: } 2351 \mathrm{mg} / \mathrm{l} ; \\
\text { OCB+; Al: } 7.0\end{array}$ \\
\hline $\begin{array}{l}\text { (a) } 11 \mathrm{~d} \text {, (b) } 12 \mathrm{~m} \text { after start of } \\
2 \mathrm{w} c\end{array}$ & $\begin{array}{l}\text { a) Improvement in all neuropsycho- } \\
\text { logical parameters; b) stable }\end{array}$ & $\begin{array}{l}\text { a) } 27 / 30 \\
\text { b) } 29 / 30\end{array}$ & $\begin{array}{l}\text { a) IDSR 5: +0.733, IDSR 7: -0.280 (z-s- } \\
\text { core); a) CDT; } 7 / 9\end{array}$ & $\mathrm{Nd}$ \\
\hline (10) case report & $\begin{array}{l}\text { Attention-, memory-and executive } \\
\text { deficits }\end{array}$ & $22 / 30$ & CERAD, WMS-R, MT, CDT & $\begin{array}{l}\text { Cc: } 61 / \mu l ; \text { tp: } 3690 \mathrm{mg} / \mathrm{l} ; \\
\text { OCB+; Al: } 7.4\end{array}$ \\
\hline $6 \mathrm{w}$ (CSF), $6 \mathrm{~m}$ after $3 \mathrm{w} \mathrm{c}$ & $\begin{array}{l}\text { Major improvement; MRI not im- } \\
\text { proved }\end{array}$ & $28 / 30$ & Improvement (see Figs. 1, 2 and 3) & $\begin{array}{l}\text { Cc: } 17 / \mu l ; \text { tp: } 1792 \mathrm{mg} / \mathrm{l} ; \\
\text { OCB+; Al: } 14.1\end{array}$ \\
\hline
\end{tabular}

$a$ amoxicillin $3 \times 500 \mathrm{mg} /$ die orally, Al Borrelia burgdorferi-specific antibody index, Alb albumin, $c$ ceftriaxone $2 \mathrm{~g} / \mathrm{die}$ intravenously, CAT computerized alertness test, Cc cell count, CDT Clock-drawing test, CERAD Consortium to Establish a Registry for Alzheimer's Disease test, CSF cerebrospinal fluid, $d$ days, IDSR Intercategorical Delayed Selective Reminding test, $I V$ intravenously, $m$ months, MMSE Mini Mental State Examination test, MRI magnetic resonance imaging, MT Memo test, Nd not done, Nm not mentioned, OCB oligoclonal banding, $s d$ standard deviation, $t p$ total protein, $T X$ antibiotic treatment, vf verbal fluency, $w$ weeks, WAIS Wechsler Adult Intelligence Scale, WMS- $R$ Wechsler Memory Scale-Revised, $y$ year 


\section{Lyme Borreliosis}

\begin{tabular}{|l}
$\square$ 1. TMT-A \\
$\square$ 2. TMT-B \\
$\square$ 3. TMT-B/TMT-A \\
$\square$ 4. WL learning \\
$\square$ 5. WL free recall \\
$\square$ 6. WL recall/learning \\
$\square$ 7. WL recognition \\
$\square$ 8. CF \\
$\square$ 9. CF free recall \\
$\square$ 10. CF recall/CF \\
$\square$ 10. BNT \\
$\square$ 11. VF-semantic \\
$\square$ 12. VF-phonematic \\
$\square$ 13. MMSE
\end{tabular}

Z-score

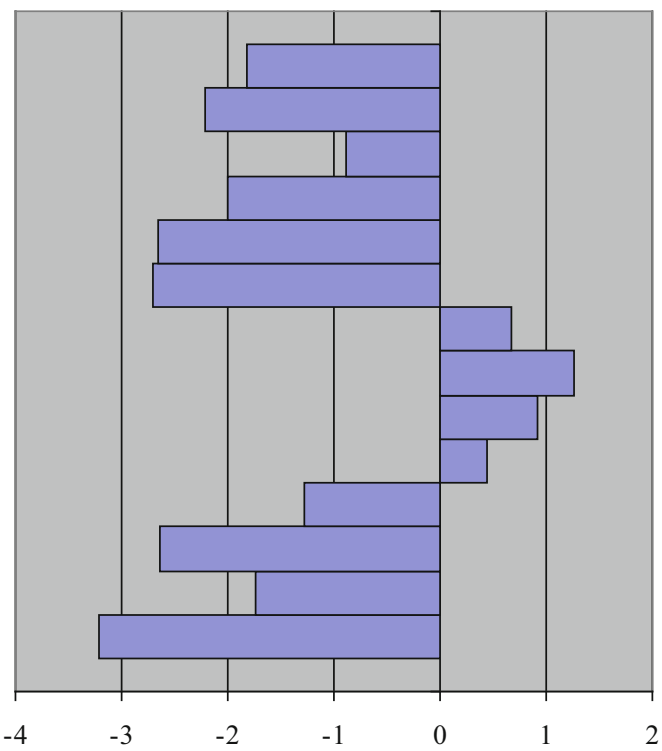

Fig. 1 Patient 10, CERAD-Plus test profile a 4 months prior to antibiotic treatment and $\mathbf{b} 18$ months after antibiotic treatment. BNT Boston naming test, CF copy figures, MMSE Mini

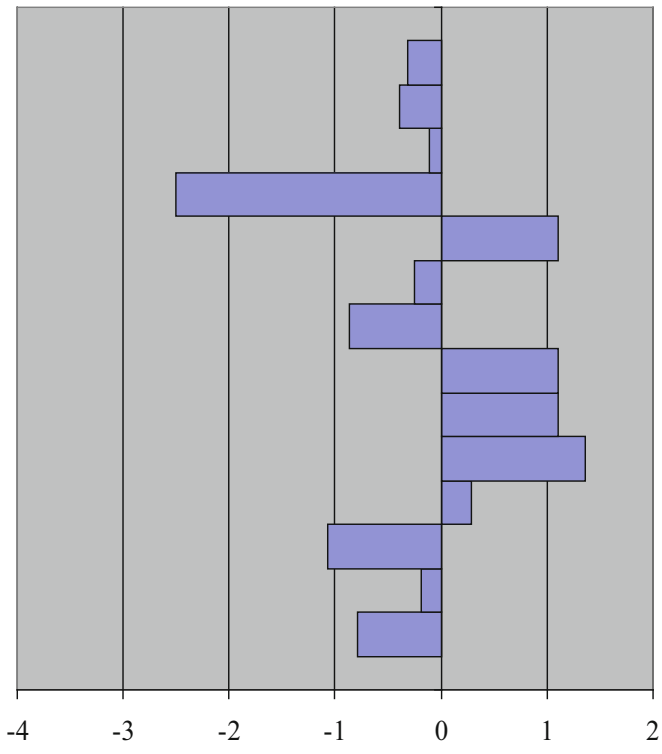

b
Mental State Examination, TMT trail making test, $V F$ verbal fluency, $W L$ word list, $z$-score (corrected for age, gender and educational level): negative values $=$ worse

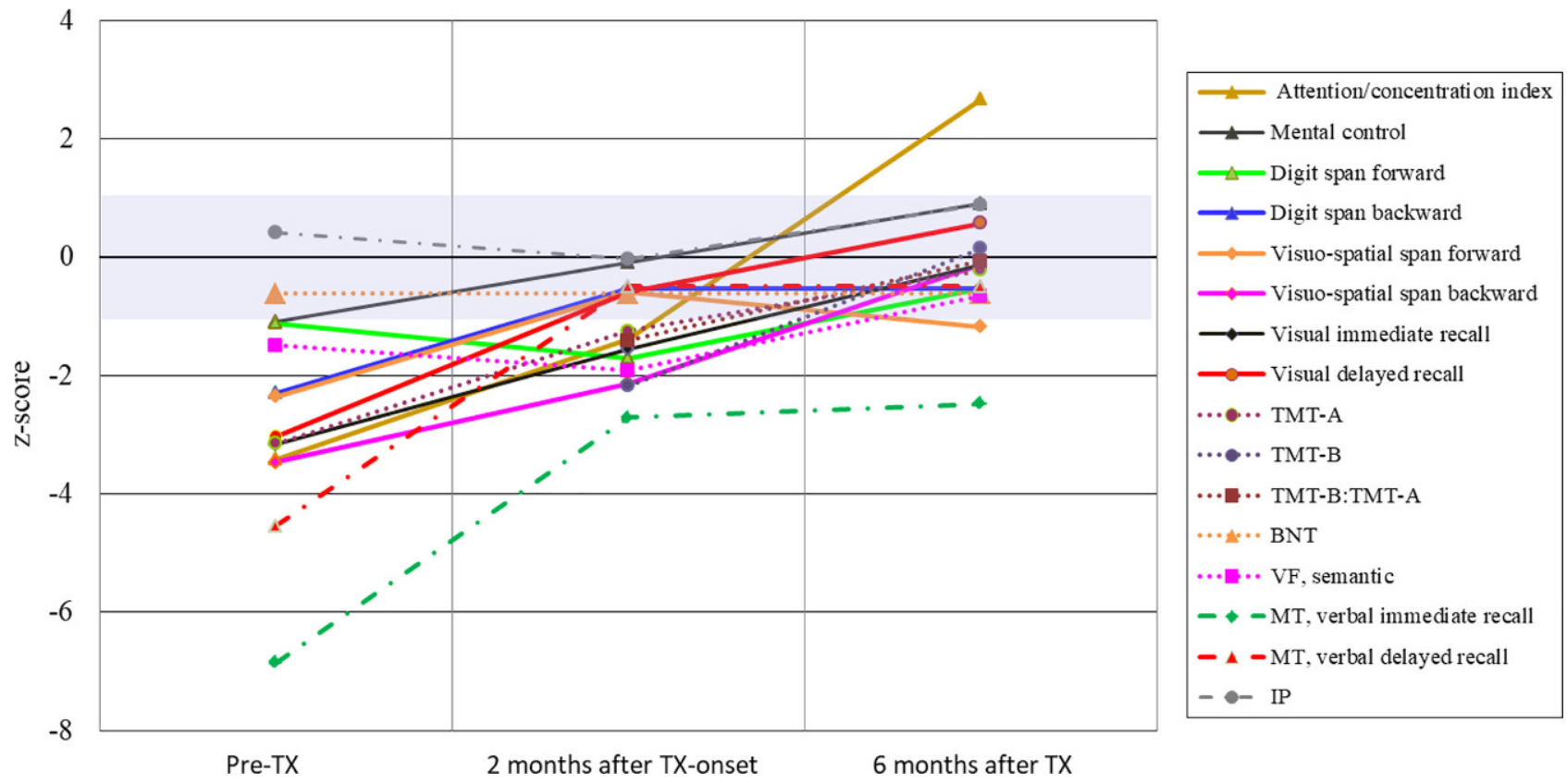

Fig. 2 Patient 10, neurocognitive assessment. Solid lines: WMS-R subtests; round dots: CERAD-Plus subtests: $B N T$ Boston naming test, TMT Trail making test, $V F$ verbal fluency; dash-dot lines: IP ideomotor praxia, MT Memo test TX:

Neurological symptoms and impaired cognitive functions, although persistent for a year, recovered rapidly within a few weeks (Figs. 1, 2 and 3) and so did the pathological CSF findings (Table 2). A follow-up FDG-PET examination showed the left frontotemporal hypometabolism in remission, while this was not the case for the cystic lacunar lesion in the left striatum.

antibiotic treatment; violet field: normal range (z-score -1 to +1); TMT-B z-score for Pre-TX not shown, calculation due to delayed performance (598s) not meaningful

A new and clinically silent small right thalamic lesion was detected that was not present in the pretreatment MRI (Fig. 4). The Consortium to Establish a Registry for Alzheimer's Disease (CERAD) test battery at the last follow-up in April 2014 scored within the agedependent normal range with the exception of verbal learning and semantic verbal fluency (Fig. 1). In 

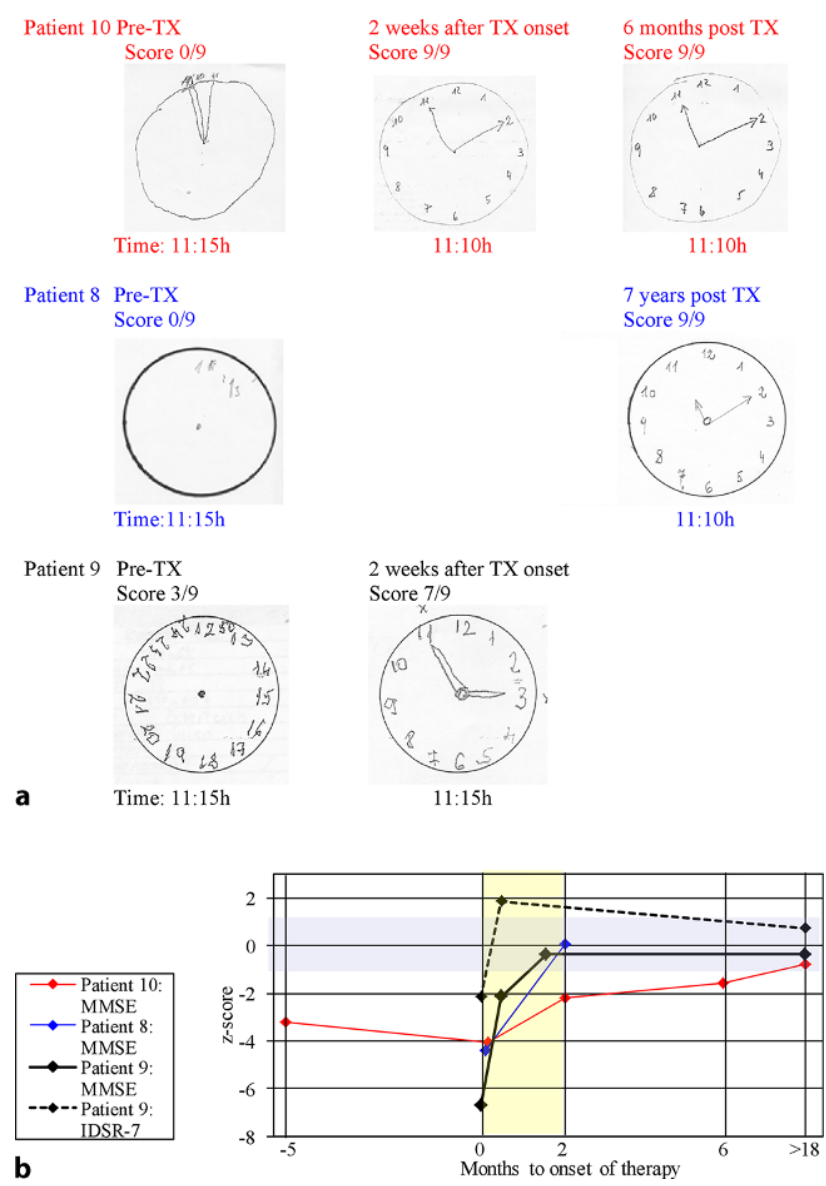

Fig. 3 Clock-drawing test (a), Mini Mental State Examination test and Intercategorical Delayed Selective Reminding test (b) before and after antibiotic therapy. IDSR Intercategorical Delayed Selective Reminding test, MMSE Mini Mental State Examination test, TX antibiotic treatment, violet field: normal range (z-score: -1 to +1$)$, yellow field: first 2 months after antibiotic therapy

a telephone call in February 2018 at the age of 82 years, the patient reported no gait problems or cognitive impairment and had just returned from a trip to Cuba.

Patient 8 (Table 1 and 2), an 80-year-old female, was admitted to hospital in Mai 2006 because of gait disturbances, cognitive decline and frequent falls. The cranial computed tomography (cCT) showed enlarged ventricles and NPH was initially suspected. During a spinal tap test (STT) for predicting response to shunting, the CSF unexpectedly showed signs of an aseptic meningitis and LNB was revealed. The symptoms resolved completely after antibiotic treatment with ceftriaxone $2 \mathrm{~g}$ daily for 4 weeks (Table 2; Fig. 3b; for more details see reference [7]).

The patient had a follow-up visit in 2013 when living independently in a retirement home, was fully ambulatory, oriented and showed no signs of cognitive impairment in the Clock-drawing test (CDT) (Fig. 3a).

Patient 9 (Tables 1 and 2), a 71-year-old female, was admitted to the psychiatric department of our hospital in November 2010 with the initial diagnosis of rapidly progressing dementia or delirium. A history of mild forgetfulness which was noticed half a year prior to the beginning of rapid deterioration and a slight mesiotemporal atrophy in the MRI together with a pathological score in the Mini Mental State Examination (MMSE) test and in the Intercategorical Delayed Selective Reminding Test (IDSR) supported the initial diagnosis of primary dementia (Table 2; Fig. 3). Short periods of altered consciousness on admission were compatible with a delirious state. Later, the patient's daughter reported a tick bite followed by a widespread rash. Thus, LNB was suspected and confirmed by CSF investigations (Table 2). The patient's cognitive impairment remitted within the 2 weeks of antibiotic treatment with $2 \mathrm{~g}$ ceftriaxone/day (Fig. 3). When discharged from the hospital the patient was still on galantamine and mirtazapine (for more details see reference [8]).

At the first follow-up investigation after 1 month the patient scored 29/30 ( $\mathrm{z}-0.375)$ in the MMSE and treatment with galantamine was stopped. At the second follow-up 1 year after treatment of LNB cognition was normal with MMSE 29/30, and mirtazapine could be stopped. At another follow-up 5 years and 5 months after treatment of LNB, cognition was stable, and testing of episodic memory by the IDSR 7 now showed a $\mathrm{z}$-score of +0.734 , i.e. above the mean for females of the same age, which strongly argued against any dementing process (Fig. $3 b$ ).

\section{Reports from the literature}

The literature search by using stringent diagnostic criteria disclosed only seven additional patients with dementia as a leading symptom of definitive LNB. These cases were reported in detail, so they can serve for the description of characteristic features. The data of all 10 patients are summarized in Table 1 and 2.

\section{Frequency of dementia-like syndromes among patients with Lyme neuroborreliosis}

In a search for adult inpatients with the diagnosis LNB at our neurological department over a period of 14 years, 48 other patients with definitive LNB were identified. The vast majority $(n=45)$ were diagnosed with Bannwarth's syndrome (BS), a well characterized painful radiculoneuritis. Subacute meningoencephalitis $(n=1)$, facial palsy without other symptoms of BS $(n=1)$ and acrodermatitis chronica atrophicans-associated neuropathy $(n=1)$ were other rare diagnoses. Patient records prior to 2004 were not available for the search, but the authors do not remember having seen patients with dementia-like syndromes and chronic LNB during the 20 years previous to 2004, a period when serodiagnostic tests were already available. Thus, the frequency of patients with dementia-like syndromes amongst adult patients with 

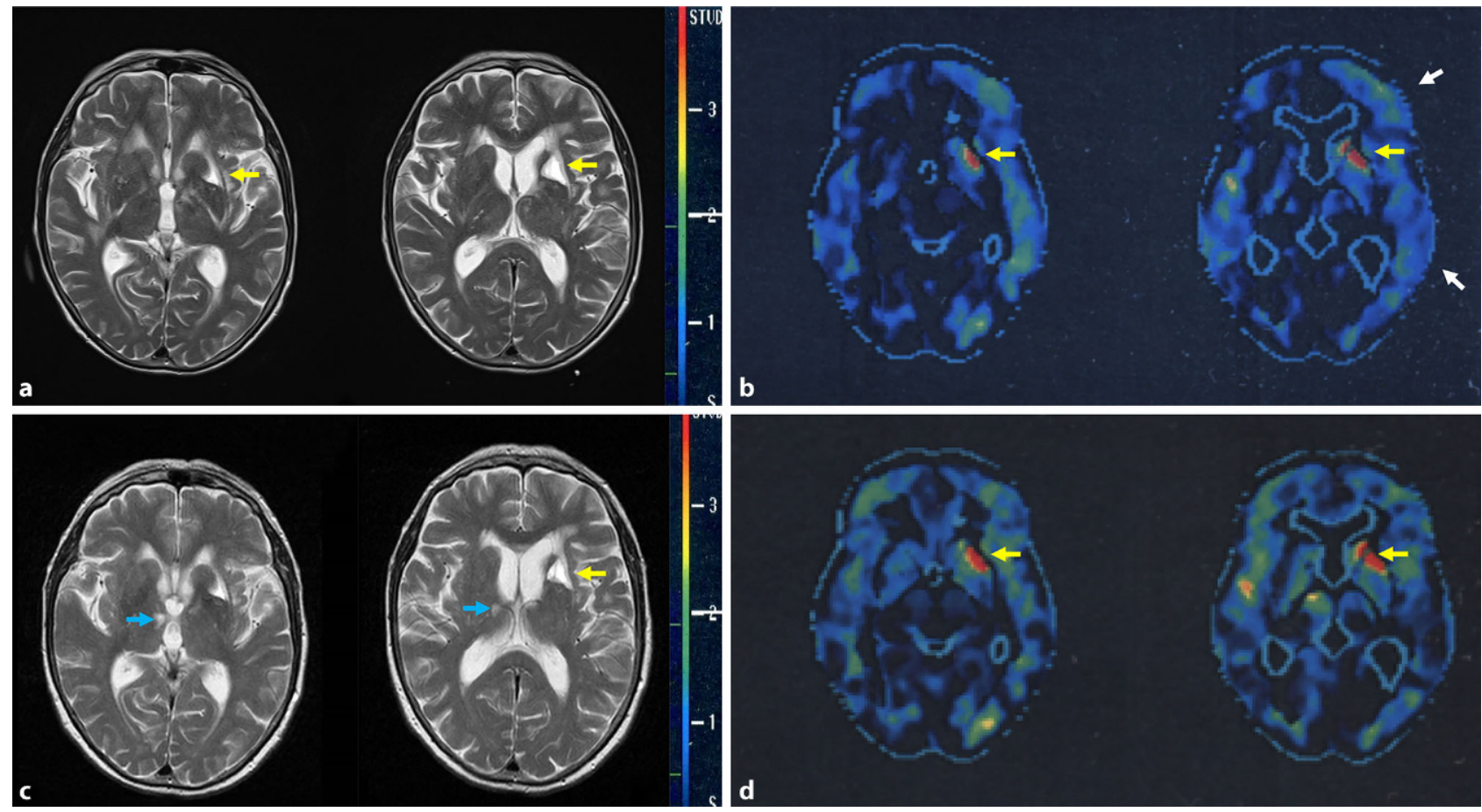

Fig. 4 Patient 10, neuroimaging. MRI (T2-weighted images) 10 days before (a) and 9.5 months after antibiotic therapy (c). FDG-PET 2 months before (b) and 9.5 months after onset of antibiotic therapy (d). Metabolism evaluated by FDG-PET is presented as comparison with age matched healthy controls. Standard deviation is displayed with a red to dark blue scale.

LNB in the setting of a tertiary health facility was well below $6 \%$.

\section{Discussion}

The cases with secondary dementia reported here are manifestations of chronic progressing meningoencephalomyelitis in LNB, originally reported by Ackermann in 1985 [16]. This rare disorder is caused by an active and ongoing CNS inflammatory process and occurs in about $2-6 \%$ of all cases with LNB [17-19]. It must not be mistaken for Lyme encephalopathy [20], "pure Lyme dementia" [2] or for neuropsychological complaints of the "post Lyme disease syndrome", conditions without proof of an ongoing CNS infection [21]. The largest case series of this rare disorder includes 44 patients and shows a broad clinical spectrum. Spastic paraparesis or tetraparesis, ataxia, incontinence, dysarthria and hearing impairment were the most frequent symptoms. While mild impairment of memory and concentration was seen in 12 of the 44 patients, 2 patients "disclosed severe mental disorders with dementia-like deficiencies, loss of orientation and even altered consciousness" [59]. In a few cases of CNS-LNB, cognitive impairment was so dominant that they were initially misdiagnosed as rapidly progressing primary dementia. A joint presentation of these cases may be helpful to avoid diagnostic pitfalls. In the following, clinical features

White arrows show hypometabolism in the left frontotemporal region before therapy (b) which is absent after therapy (d). Yellow arrows show left striatal lacunar lesion (a and $\mathbf{b}$ ), not reversible after therapy (c and d). Blue arrow show small right thalamic vascular lesion (c), not seen in (a)

which raise suspicion of LNB in dementia-like syndromes are outlined.

\section{History}

Previous tick bites, EM or symptoms compatible with early LNB like BS were remembered only by a small minority of patients with chronic LNB or by their relatives. When patients did remember, chronic progressive encephalomyelitis followed 2 months to 2 years later [22, 23]. Thus, EM or other characteristic symptoms of early LB 1-2 years before the onset of dementia may if untreated serve as an indicator for chronic LNB.

\section{Disease course}

Dementia in LNB showed a rapid course reaching a moderate stage of dementia within 6-12 months from onset of symptoms. Aside from dementia in Creutzfeldt-Jakob disease which occurs rapidly, most neurodegenerative dementias develop slowly with the possible exception of DLB and corticobasal degeneration. Disorders that commonly lead to a slowly progressive dementia such as $\mathrm{AD}$ and frontotemporal dementia rarely present with a rapid course [24]. Cognitive impairment with sudden onset or with stepwise deterioration in combination with hemiparesis, hemianopsia or diplopia indicating vascular dementia [25] 
have also been reported in rare cases of vasculitis due to LNB and might be the cause of irreversible dementia in LNB [26-28].

\section{Somatic symptoms}

Weight loss is another symptom observed in LB. It is also compatible with the diagnosis of $\mathrm{AD}$ [29] but when it occurs in chronic LNB, it can be more pronounced, reaching up to $20 \mathrm{~kg} /$ year [12, 22, 30-32], while weight loss, which is seen in almost all AD patients is less prominent and is on average $2 \mathrm{lb}(0,9 \mathrm{~kg}) /$ year [33].

Headache, nausea, malaise and vomiting, probably signs of chronic meningitis, are not symptoms of degenerative dementias but might be associated with secondary dementia and thus also with chronic LNB as was the case in 2 of our 3 patients. Sensorineural hypacusis, another symptom associated with chronic meningitis and not recorded in our patients, was a characteristic symptom in other cases of chronic CNS-LNB [17]. Tremor was reported in all three of our patients, in two of them as action tremor. In the third patient, who showed resting and position tremor, the latter dominated.

Gait disturbances at the onset or early in the disease which was observed in all cases of this study, makes the diagnosis of a probable AD uncertain or unlikely [29]. It presents as postural instability, ataxia or as broad-based, short-stepped gait. A walker had to be used by two out of three and falls were reported by all three of our patients. Progressive gait disturbance in combination with voiding dysfunction and dementia forms the clinical triad of NPH symptoms [34] and in 5 of the 10 patients probable NPH was the initial diagnosis (patients 2, 4, 5, 7 and 8 in Table 1). When they had a STT, performed for predicting response to shunting, CSF pleocytosis was unexpectedly detected and further CSF analyses disclosed the correct diagnosis of secondary NPH due to LNB. Secondary NPH was also seen in several other cases of LNB not included in this study [13, 17, 30, 35, 36]. Results of STT were reported in four patients (Table 2 and reference [30]) and two of them showed improvement of symptoms. Details on the improvement evaluation were missing. Of the 68 patients with LNB reported from a retrospective data analysis 5 had chronic LNB. All 5 had symptoms indicative of NPH, but lumbar puncture with drainage of CSF did not change the symptoms [13]. Furthermore, the clinical symptoms between patients with and without MRI signs of NPH did not significantly differ in our patients. Whether CSF absorption difficulties, CNS inflammation or the combination of both, were the cause of the cognitive decline in these cases remains a matter of discussion [7].

\section{Neuropsychological assessment}

Results of the MMSE reported in 7 of the 10 patients were in accordance with mild $(n=3)$ to moderate $(n=4)$ dementia. All three of our patients had a low score in the categories recall, orientation and complex commands, and two of the three also in the category attention. Scores in the CDT, another global screening test for dementia, also showed signs of marked cognitive impairment in all three patients (Fig. 3). Patients 10 and 9 had additional tests. In patient 9, episodic memory investigated with the IDSR was significantly reduced, but 11 days after onset of antibiotic therapy, MMSE, CDT and IDSR scored already in a range no longer consistent with dementia. Patient 10 had extensive neuropsychological testing including subtests from CERAD and Wechsler Memory Scale-Revised (WMS-R) test battery. The results showed deficits involving memory, attention, psychomotor speed, orientation and executive functioning, altogether consistent with subcortical dementia. Deficits of verbal memory retrieval by spared verbal recognition found in this patient, speak against primary dementia and $\mathrm{AD}$ but for secondary memory impairment and are a strong indicator for subcortical dementia [37]. Similar results have been seen in the only other patient also tested with a CERAD test battery (patient 5, Table 2).

\section{Neuroimaging}

Mild ventricular enlargement was seen in 6 of the 10 patients. Different WML, patch-like, symmetrical confluent, periventricular subependymal or lacunar, were reported. Lacunar lesions in chronic LNB are most likely due to small and medium-sized meningeal vessel vasculitis, as disclosed by autopsy [38]. Of the 9 patients with MRI examinations one had no WML at all. Patient 6 with initially large symmetrical WML that were similar to those seen in patient 10 , also showed meningeal gadolinium enhancement. In a MRI follow-up 5 years later, surprisingly, most of the original lesions had resolved [39]. The MRI results remained unchanged in the other case reports with follow-up investigations reported. This may be due to the shorter follow-up intervals of 18 months or less. Of the patients two had FDG-PET examinations: one patient with suspected $\mathrm{AD}$ and no MRI-WML had a normal glucose metabolism (patient 9 Table 1), the other, who had bilateral large WML and a lacunar lesion in the left striatum in the MRI examination, showed pathological FDG-PET results. In addition to the expected hypometabolism corresponding with the lacunar lesion, hypometabolism in a left cortical frontotemporal region was also detected. The latter was reversible in a posttreatment follow-up investigation and might have been due to hypoperfusion. The small additional thalamic lesion which was detected in an MRI followup (Fig. 4) did not correspond to the continuing clin- 
ical improvement. Whether it developed shortly before or during the treatment period or later remains unclear. Altogether, results of MRI and FDG-PET examinations did not show a uniform pattern.

\section{Treatment}

Results of antibiotic treatment in 9 of 10 patients were excellent, even in those 3 patients with only a 2 -week course of ceftriaxone. One patient treated with intravenous benzylpenicillin for 2 weeks continued to need supervision and help. In most patients improvement of symptoms was reported already within few days of antibiotic treatment. This was also the case in the patient with prolonged antibiotic treatment who received 2 weeks ceftriaxone followed by oral amoxicillin for 3 months (patient 5, Table 2). The CSF pleocytosis, elevated total protein and elevated lactate improved parallel to the clinical remission, while OCB and AI persisted. Persisting AI and OCB in otherwise normal CSF are frequently seen in adequately treated LNB and should not be interpreted as an ongoing active infection [40]. Relapses or ongoing worsening were not observed. Altogether, there was no indications for a prolonged antibiotic therapy in our patients.

\section{Pathogenesis}

The pathogenesis of chronic encephalomyelitis in LNB is not yet fully understood. Focal inflammation, demyelination, vasculitis with subsequent ischemic lesions and autoimmune phenomena have been thought to play a role. Only very few pathological studies on CNS specimens exist and described leptomeningitis, vasculitis and focal inflammation in the CNS [38, 41]. Animal models of LNB have demonstrated that invasion of the CNS with Borreliae induces a strong, cytokine-driven inflammatory reaction. This causes pathological alterations similar to those seen in human LNB. Dexamathasone prevented these pathological alterations although Borelliae persisted [42]. This could explain the alternating disease course with a tendency to improvement in a case report on chronic CNS-LNB, which was treated with corticosteroids and azathioprine for 2.5 years. Finally, the correct diagnosis was established and the patient had a full remission after a 2 weeks course of $3 \times 5$ million units iv penicillin G/day [43]. Secondary $\mathrm{NPH}$ reported in half of the patients, may also play an additional role in the development of dementialike syndromes.

\section{Conclusion}

Dementia-like syndromes in LNB belong to the broad clinical spectrum of chronic CNS-LNB, an active and ongoing inflammatory disorder of brain, spinal cord, meninges and leptomeningeal vessels. The clinical manifestations of this rare disorder depend on the neurological structures which are primarily involved. The full clinical picture of progressive encephalomyelitis in LNB may mimic chronic progressing multiple sclerosis [16]. Cases with predominant meningeal involvement have been mistaken for tuberculous meningitis [44]. Other rare cases present as extrapyramidal $[45,46]$ or as psychiatric disorders, such as schizophrenia-like psychosis [47-50], catatonia [51] or mania [52]. In all cases with dementialike syndromes reported in our review, LNB was originally not taken into consideration. This justifies the aim to point to characteristic signs and symptoms of this rare manifestation of chronic CNS-LNB. The detection should result in CSF examinations including determination of $\mathrm{Bb}$-specific $\mathrm{AI}$ which discloses the correct diagnosis. Even in chronic LNB, early antibiotic treatment is essential and can prevent irreversible sequelae.

Acknowledgements The authors would like to thank the following persons: Univ. Doz. Dr. J. Spatt, NRZ Rosenhügel, for the data of Fig. 1, Univ. Prof. Dr. T. Leitha, Department of Nuclear Medicine, for the FDG-PET pictures and Mag. Eva Kraxberger, Dept. of Psychiatry, SMZ-Ost-Donauspital for performing neuropsychological tests. Parts of the study were presented at the 11th International Conference on Lyme Borreliosis and Other Tick-borne Diseases, 18.-21.08.2013, Boston MA USA (Poster B010)

Funding Open access funding provided by Medical University of Vienna.

Conflict of interest W. Kristoferitsch and G. Stanek are unpaid steering committee members of the ESCMID Study Group for Lyme Borreliosis (ESGBOR). F. Aboulenein-Djamshidian, J. Jecel, H. Rauschka, M. Rainer and P. Fischer declare that they have no competing interests.

Open Access This article is distributed under the terms of the Creative Commons Attribution 4.0 International License (http://creativecommons.org/licenses/by/4.0/), which permits unrestricted use, distribution, and reproduction in any medium, provided you give appropriate credit to the original author(s) and the source, provide a link to the Creative Commons license, and indicate if changes were made.

\section{References}

1. Mygland A, Ljøstad U, Fingerle V, et al. EFNS guidelines on the diagnosis and management of European Lyme neuroborreliosis. Eur J Neurol. 2010;17(1):8-16.

2. Blanc F, Philippi N, Cretin B, et al. Lyme neuroborreliosis and dementia. JAlzheimers Dis. 2014;41(4):1087-93.

3. Miklossy J. Alzheimer's disease-a neurospirochetosis. Analysis of the evidence following Koch's and Hill's criteria. J Neuroinflammation. 2011;8:90.

4. Itzhaki RF, Lathe R, Balin BJ, et al. Microbes and alzheimer's disease. JAlzheimers Dis. 2016;51(4):979-84.

5. American Psychiatric Association. Diagnostic and statistical manual of mental disorders. 4th ed. Arlington: APA Press; 1994.

6. American Psychiatric Association. Diagnostic and statistical manual of mental disorders. 5th ed. Arlington: APA Press; 2013. 
7. Aboul-Enein F, Kristoferitsch W. Normal pressure hydrocephalus or neuroborreliosis? Wien Med Wochenschr. 2009;159(1/2):58-61.

8. Rainer M. Demenz durch Neuroborreliose. Psychopraxis. 2011;14(4):24-7. https://doi.org/10.1007/s00739-0110304-2.

9. Bremell D, Säll C, Gisslén M, Hagberg L. Lyme neuroborreliosis in HIV-1 positive men successfully treated with oral doxycycline: a case series and literature review. J Med Case Rep. 2011;5:465.

10. García-Moreno JM, Izquierdo G, Chacón J, Angulo S, Borobio MV. Neuroborreliosis in a patient with progressive supranuclear paralysis. An association or the cause? Rev Neurol. 1997;25(148):1919-21.

11. Waniek C, Prohovnik I, Kaufman MA, Dwork AJ. Rapidly progressive frontal-type dementia associated with Lyme disease. J Neuropsychiatry Clin Neurosci. 1995;7(3):345-7.

12. Verma V, Roman M, Shah D, Zaretskaya M, Yassin MH. A case of chronic progressive Lyme encephalitis as a manifestation of late Lyme neuroborreliosis. Infect Dis Rep. 2014;6(4):5496.

13. Schwenkenbecher P, Pul R, Wurster U, et al. Common and uncommon neurological manifestations of neuroborreliosis leading to hospitalization. BMC Infect Dis. 2017;17(1):90. https://doi.org/10.1186/s12879-016-2112-

14. Reeß J, Mauch E, Kornhuber HH. Subakutes organisches Psychosyndrom als klinische Manifestation einer Infektion mit Borrelia burgdorferi im Stadium II ohne weitere neurologischeStörungen. Nervenarzt. 1991;62(8):514-5.

15. GuindaJM,LópezDLM, MartínezPérez-BalsaA, VillamilCI, Jove Castelo MJ. Deterioro cognitive de rapida instauracion: neuroborreliosis y proteina $14-33$ positiva. Rev Chilena Infectol. 2011;28(3):274-5. Jun.

16. Ackermann R, Gollmer E, Rehse-Küpper B. Progressive Borrelien-Enzephalomyelitis. Chronische Manifestationen der Erythem-migrans-Krankheit am Nervensystem. Dtsch MedWochenschr. 1985;110(26):1039-42.

17. Hansen K, Lebech AM. The clinical and epidemiological profile of Lyme neuroborreliosis in Denmark 1985-1990. A prospective study of 187 patients with Borrelia burgdorferi specific intrathecal antibody production. Brain. 1992;115(Pt2):399-423.

18. Oschmann P, Dorndorf W, Hornig C, Schäfer C, Wellensiek HJ, Pflughaupt KW. Stages and syndromes of neuroborreliosis. J Neurol. 1998;245(5):262-72.

19. Koedel U, Fingerle V, Pfister HW. Lyme neuroborreliosisepidemiology, diagnosis and management. Nat Rev Neurol. 2015;8(11):446-65

20. Halperin JJ, Krupp LB, Golightly MG, Volkman DJ. Lyme borreliosis-associated encephalopathy. Neurology. 1990;40(9):1340-3.

21. FederHM, Johnson B, O'ConnelS, Shapiro E, SteereAC, et al. A critical appraisal of "chronic Lyme disease". N Engl J Med. 2007;357(14):1422-30.

22. Weder B, Wiedersheim P, Matter L, Steck A, Otto F. Chronic progressive neurological involvement in Borrelia burgdorferi infection. J Neurol. 1987;234(1):40-3.

23. Oschmann P, Dorndorf W, Hornig C, Schäfer C, Wellensiek HJ, Pflughaupt KW. Stages and syndromes of neuroborreliosis. J Neurol. 1998;245(5):262-72.

24. Geschwind N, Haman A, Miller BL. Rapidly progressive dementia. NeurolClin. 2007;25(3):783-807.

25. Román GC, Tatemichi TK, Erkinjuntti T, et al. Vascular dementia: diagnostic criteria for research studies. Report of the NINDS-AIREN International Workshop. Neurology. $1993 ; 43(2): 250-60$.
26. Almoussa M, Goertzen A, Fauser B, Zimmermann CW. Stroke as an unusual first presentation of Lyme disease. Case Rep Neurol Med. 2015;2015:389081. https://doi.org/ $10.1155 / 2015 / 389081$.

27. Back T, Grünig S, Winter Y, et al. Neuroborreliosis-associated cerebral vasculitis: long-term outcome and healthrelated quality of life. J Neurol. 2013;260(6):1569-75.

28. Garkowski A, Zajkowska J,Zajkowska A, et al. Cerebrovascular manifestations of Lyme neuroborreliosis-a systematic review of published cases. Front Neurol. 2017;8:146. https://doi.org/10.3389/fneur.2017.00146.

29. McKhann G, Drachman D, Folstein M, et al. Clinical diagnosis of Alzheimer's disease: report of the NINCDSADRDA Work Group under the auspices of Department of Health and Human Services Task Force on Alzheimer's Disease. Neurology. 1984;34(7):939-45.

30. Druschky K, Stefan H, Grehl H, Neundörfer B. Symptomatic normal-pressure hydrocephalus. A complication of chronic Lyme neuroborreliosis. Nervenarzt. 1999;70(6):556-9.

31. Winter EM, Rothbarth PH, Delfos NM. Misleading presentation of acute Lyme neuroborreliosis. BMJ Case Rep. 2012; https://doi.org/10.1136/bcr-2012-006840. Published oneline: 6December 2012.

32. Malick C, Montanéde la Roque P, Boilevin L, et al. Lyme disease disclosed by pseudoneoplastic weight loss. Rev Med Interne. 2002;23(2):206-7.

33. White H, Pieper C, Schmader KJ. The association of weight change in Alzheimer's disease with severity of disease and mortality: a longitudinal analysis. J Am Geriatr Soc. 1998;46(10):1223-7.

34. Hakim S, Adams RD. The special clinical problem of symptomatic hydrocephalus with normal cerebrospinal fluid pressure, observations on cerebrospinal fluid hydrodynamics. J Neurol Sci. 1965;2(4):307-27.

35. Hänny PE, Häuselmann HJ. Die Lyme Krankheit aus der Sicht des Neurologen. Schweiz Med Wochenschr. 1987;117(24):901-15.

36. Viader F, Poncelet AM, Chapon F, et al. Les formes neurologiques dela maladie de Lyme: 12 cas. RevNeurol (paris). 1989;145(5):362-336.

37. Schmidtke K, Hüll M. Neuropathologische Untersuchung von Patienten bei Demenzverdacht. Nervenheilkunde. 2007;26(8):651-837.

38. Kuntzer T, Bogouslavsky J, Miklossy J, et al. Borrelia rhombencephalomyelopathy. Arch Neurol. 1991;48(8): 832-6.

39. Steinbach JP, Melms A, Skalej M, Dichgans J. Delayed resolution of white matter changes following therapy of B burgdorferi encephalitis. Neurology. 2005;64(4):758-9. https://doi.org/10.1212/01.WNL.0000152048.34121.E1.

40. Hammers-Berggren S, Hansen K, Lebech AM, Karlsson M. Borrelia burgdorferi-specific intrathecal antibody production in neuroborreliosis: a follow-up study. Neurology. 1993;43(1):169-75.

41. Meurers B, Kohlhepp W, Gold R, Rohrbach E, Mertens HG. Histopathological findings in the central and peripheral nervous systems in neuroborreliosis. J Neurol. 1990;237(2):113-6.

42. Ramesh G, Didier PJ, al England JD. Inflammation in the pathogenesis of neuroborreliosis. Am J Pathol. 2015;185(5):1344-60.

43. Kollikowski HH, Schwendemann G, Schulz M, Wilhelm H, Lehmann HJ. Chronic borrelia encephalomyeloradiculitis with severe mental disturbance: immunosuppressive versus antibiotic therapy. J Neurol. 1988;235(3):140-2. 
44. Kohler J, Kern U, Kasper J, Rhese-Küpper B, Thoden U. Chronic central nervous system involvement in Lyme borreliosis. Neurology. 1988;38(6):863-7.

45. Kohlhepp W, Kuhn W, Krüger H. Extrayramidal features in central Lyme borreliosis. Eur Neurol. 1989;29(3):150-5.

46. PiccoloL, Thiella G, Sterzi R, Colombo N, DefantiCA.Chorea as a symptom of neuroborreliosis: a case study. Ital J Neurol Sci. 1998;19(4):235-9.

47. RoelckeU, BarnettW, Wilder-Smith E, Sigmund D, HackeW. Untreated neuroborreliosis: Bannwarth syndrome evolving into acute schizophrenia-like psychosis. A case report. J Neurol. 1992;239(3):129-31.

48. van den Bergen HA, Smith JP, van der Zwan A. Lyme psychosis. Ned Tijdschr Geneeskd. 1993;137(41):2098-100.

49. Hess A, Buchmann J, Zettl UK, et al. Borrelia burgdorferi central nervous infection presenting as ongoing schizophrenialike disorder. Biol Psychiatry. 1999;45(6):795.

50. Markeljević J, Sarac H, Rados M. Tremor, seizures and psychosis in a patient with chronic Lyme neuroborreliosis (LNB). Coll Andropol. 2011;35(Suppl 1):313-8.

51. Pfister HW, Preac-Mursic V, Wilske B, et al. Catatonic syndrome in acute severe encephalitis due to Borrelia burgdorferi infection. Neurology. 1993;43(2):433-5.
52. Passareanu AR, Mygland A, Kristensen O. A women in her 50s with manic psychosis. Tidskr Nor Legeforen. 2012;132:537-9.

53. Carlsson M, Malmvall BE. Borrelia infection as a cause of presenile dementia. Lancet. 1987;330(8562):798. https:// doi.org/10.1016/S0140-6736(87)92528-1.

54. DanekA, Uttner I, YousryT, Pfister HW. Lymeneuroborreliosis disguised as normal pressurehydrocephalus. Neurology. 1996;46(6):1743-5.

55. Pennekamp A, Jaques M. Chronische Neuroborreliose mit Gangataxie und kognitiven Störungen. Praxis (Bern 1994). 1997;86(20):867-9.

56. Etienne M, Carvalho P, Fauchais AL, et al. Lyme neuroborreliosis revealed as a normal pressure hydrocephalus: a cause of reversible dementia. JAm Geriatr Soc. 2003;51(4):579-80.

57. Andersson C, Nyberg C, Nyman D. Rapid development of dementia of an elderly person, diagnosis and successful treatment. Duodecim. 2004;120(15):1893-6.

58. Topakian R, Artemian H, Metschitzer B, et al. Dramatic response to a 3-week course of ceftriaxone in late neuroborreliosis mimicking atypical dementia and normal pressure hydrocephalus. J Neurol Sci. 2016;366:146-8.

59. Ackermann R, Rehse-Küpper B, Gollmer E, Schmidt R. Chronic neurologic manifestations of erythema migrans borreliosis. Ann NYAcad Sci. 1988;539:16-23. 